\title{
Politicisation of the Eurozone crisis in Finland: adaptation toward the radical right?
}

\author{
Sanna Salo (1) and Jens Rydgren \\ Department of Sociology, Stockholm University, Stockholm, Sweden
}

\begin{abstract}
This paper analyses the politicisation of the Eurozone crisis in Finnish public debate, in May-November 2010. We emphasise how the mainstream parties responded to the radical right Finns Party's framing, in addition to two context factors: first, the constraints posed on domestic policymakers by EU and EMU-level decisions, and secondly, the sharp, economic downturn, encouraging a zerosum interpretation of distributive claims. To trace actor positions, we analyse 1183 actor-issue statements coded from Finland's main newspaper, Helsingin Sanomat. Our findings suggest that radical right-wing parties can benefit from the high salience of socioeconomic issues, if distributive conflict can plausibly be portrayed as a in- and out-group conflict, and that the mainstream parties did not only adopt nationalistic rhetoric as a response to the radical right-wing Finns Party's framing, but were responding to a constraints such as the diminished room for maneuver in the EMU, moving them towards the Finns Party's position.
\end{abstract}

\section{ARTICLE HISTORY}

Received 12 October 2017

Accepted 30 August 2018

\section{KEYWORDS}

Eurozone crisis; radical right; politicisation; social democratic parties; EMU; framing

\section{Introduction}

Radical right-wing parties today form an established - and substantial - part of party systems across the Euro-Atlantic area. These parties are united by their ethnic nationalism. Their overall policy objective is to safeguard the nation's majority culture and to keep the nation as ethnically homogenous as possible. Their ethnic nationalism is followed by an exclusionary attitude towards immigrants and - to varying degrees - towards other ethnic or racial minorities. They also tend to be populists in accusing elites of putting internationalism ahead of the nation and of putting their own narrow self-interests and various special interests ahead of the interests of the people (Rydgren, 2017, 2018).

These parties rely on an increasingly mixed voter base, where particularly working-class voters are likely to vote for the radical right (Arzheimer, 2018). Numerous studies have shown that working-class support for the radical right hinges on socio-cultural, rather than socio-economic, considerations (see e.g. Häusermann, Picot, \& Geering, 2013; Rydgren, 2008, 2013). The radical right caters to the traditional-authoritative socio-cultural attitudes of these voters.

Yet, in several countries the radical right increasingly mobilises support also on the socio-economic issue dimension, with a moderately pro-welfare attitude mixed with a 
hard line on borders and immigration (e.g. Michel, 2017; Rydgren, 2013). Particularly in the Nordic countries, the radical right is known to promote "welfare chauvinism", that is, generous welfare provision restricted to the in-group of ethnic nationals in a given country (Andersen \& Björklund, 1990).

This paper analyses the public debate on the Eurozone crisis in Finland, in MayNovember 2010. Earlier research has shown that socio-cultural positions rather than economic self-interest determined attitudes towards the Eurozone bailouts. Our argument contributes to existing research in two ways. First, we show that the Eurozone crisis debate represented a new type of transnational distributive conflict, where socio-economic distributive questions (who gets what) were mixed with socio-cultural questions (who belongs to the in-group, in which relations of reciprocity apply). Secondly, we show how this particular form of political conflict came about in Finland as a result of the agency of both the radical right Finns Party and the mainstream parties.

When the radical right starts to emphasize also socio-economic issues, the context of party competition changes, and the mainstream parties will have to respond. Some scholars (e.g. Häusermann et al., 2013, p. 228) have hypothesised that the centre-left will respond to the radical right challenge by adopting the welfare chauvinist position. While the socio-cultural nationalis framing may originally have been the preference of the Finns Party, the frame would not have prevailed without the support of the mainstream parties. These were bound by the constraints of Finland's EMU membership, effectively forcing them to accept participation in the costly financial rescue packages for Greece, Portugal and Ireland. Hence, adopting a harsh rhetoric that blamed the peoples of Southern European countries for Finland's burden in the EMU rescue packages was among the few political tools left for Finnish policymakers.

We consider Finland as a case that illuminates the politics brought about by the crisis in the EU more broadly. We have seen right-wing populism flourish across North-western Europe and the United States. Finland, we argue, is a representative case of the universe of the Eurozone's creditor countries. The crisis crystallized the divisions within the EMU into the Northern surplus and Southern deficit countries, and the politics that have followed the crisis have looked rather different in these two groups of countries.

Our empirical analysis is based on an original dataset consisting of 1183 actor-issue statements coded from Finland's main newspaper, Helsingin Sanomat. Methodologically, we analyse the debate using Core Sentence Analysis, a form of relational content analysis (see also Hutter \& Grande, 2014; Hutter, Grande, \& Kriesi, 2016; Kriesi et al., 2012). We argue that unlike earlier research would lead us to expect (see e.g. Grittersová, Indridason, Gregory, \& Crespo, 2016; Kriesi, 1999; Rydgren, 2007; Spies, 2013) the radical right can parties can mobilise support also on socio-economic issues.

In the next section we review key theoretical approaches to analysing radical right-wing parties and suggest a way to update these approaches, laying out our analytical framework. We then present the qualitative analysis of the debates and finally, the last section concludes.

\section{Literature review \& theoretical framework}

As discussed in the introduction, our puzzle centres on the question of how and why the radical right-wing Finns Party's preferred socio-cultural framing of the crisis became 
prevalent, with practical policy implications. In addressing this puzzle, we depart from the idea of Schattschneider (1975 [1960]) and Riker (1986), for whom "political competition is about defining or redefining the relevant dimensions of conflict" and where "new political actors have an interest in priming new dimensions that put them at a comparative advantage over established political actors" (Bornschier, 2018, p. 22). We thus look at the Eurozone crisis debate in Finland as an instance in which political conflict dimensions in Finnish EU-politics were redrawn. The Finns Party had significant influence on this process, but it could never have redrawn political battle lines by itself. The other parties had to - and did - play along. Hence, the question becomes: what enabled the Finns Party to wield influence on the framing of the crisis, and why did other parties accept the Finns Party's framing? After all, pitting states and peoples against each other was only one among possible interpretations of what was at stake.

Hence, our analytical framework will focus on two kinds of questions. First, did the Finns Party indeed advocated a strong us vs. them-framing, and did other parties adopt such framing in the course of the crisis? ${ }^{1}$ Secondly, how and why was this possible? When - under what conditions - would the mainstream parties leave their pre-crisis positions and move closer to the radical right? To these ends, we will below explore the explanations given to radical right-wing success on both the supply- and demand-sides. We will also explore what we call contextual factors, which are not easily mapped under neither the supply- nor demand-side, but which we believe have been crucial for the political outcomes observed in the crisis.

\section{Explaining radical right success: supply- and demand-side factors}

When does the radical right succeed? An important caveat here is that we are not attempting to explain, per se, electoral success of the Finns Party. The public politicisation of the Greek and Irish rescue packages in 2010 surely played a role for the Finns Party's victory in election 2011. Our focus, however, is in explaining how and why the party was successful in tweaking the agenda in public debates in the Finnish press. We argue that some of the explanations put forward in the literature may be helpful also in this task.

The political supply-side refers to the surrounding environment of party competition, in which the radical right operates, but also to internal features of the radical right-wing parties themselves (Evans \& Tilley, 2012; Rennwald \& Evans, 2014; Rydgren, 2018; Spies, 2013). We limit ourselves here to exploring the external supply-side factors and leave aside the organisational capabilities of the Finns Party. We do this because our focus in this paper is in the strategic interaction between parties (and potentially, other actors) in the public sphere, as evidenced in our newspaper data. We are interested in factors that affect the party system as a whole, as our inquiry is not limited to exploring the changes in the Finns Party only.

The external supply-side can also be referred to as political opportunity structure. An important variable here is the political supply from and strategies of the mainstream parties. If the political supply from these parties does not correspond to the demand from the electorate, a niche is created within the party system, which newcomers, such as the radical right, may exploit. Such exploitation may include the politicisation of a new issue, which existing parties have not chosen to put on the agenda. Alternatively, politicisation may include lifting an old issue and taking a more radical position 
on it. When mainstream parties converge over previously dominating issues, contributing to a decreased polarisation in the party system on that specific issue dimension, conditions are particularly favourable for mobilisation by new parties (Kitschelt, 1995; Meguid, 2005; Rydgren, 2005; Rennwald \& Evans, 2014). Such convergence may then lead to voters abandoning mainstream parties because their political supply does not match the voters' views. Research has demonstrated that convergence on the socio-economic issue dimension, in particular, will contribute to radical right-wing success, because it leads to a depoliticisation of socio-economic issues and raises the salience of socio-cultural issues, which the radical right mobilises on (e.g. Spies \& Franzmann, 2011).

Taken together, if we were to explain Finns Party's agenda-setting success by external supply-side factors, we would expect to observe, first, public attitudes that do not match existing party supply; and secondly, the Finns Party taking polarising positions on the issue on which a niche exists, thus raising the salience of that issue. The magnitude of this success, moreover, would likely hinge on a third factor, namely the extent to which mainstream parties have converged over this specific issue, and the extent to which the Finns Party are given a monopoly over the (rhetorical) opposition.

Demand-side factors, by contrast, emphasize macro-structural changes and the effect of these on voter preferences (e.g. Bornschier, 2018; Kitschelt, 1995; Kriesi et al., 2008). Most demand-side explanations centre around grievance theory, focusing on the kinds of macro-level changes that have increased feelings of relative deprivation among people. The kinds of transformations often invoked include globalisation, modernisation, technological change and liberalisation, for example in the sense of increasing the free movement of labour, capital and goods. The latter factor can increase feelings of insecurity by exposing people to competition for jobs by newcomers, by making it easier for firms to relocate activities to distant locations - resulting in job losses - or by causing abrupt shocks in capital markets, and thereby economic insecurity. In this account, radical right success has been explained by the electorate's readiness to abandon the political mainstream, because they no longer trust the ability or willingness of political elites to be on the side of the "common people". Indicators for such demand-side mechanisms being at play in the Eurozone crisis debates in Finland would include declining economic growth, rising unemployment, lowering levels of political trust and others-regarding attitudes among the public, as well as high electoral volatility.

Recently, many scholars have pointed to the limited potential of demand-side explanations to account for the observed variation in radical right-wing success across countries that have been exposed to similar structural changes. Hence, scholars such as Bornschier $(2018$, p. 2) argue for an approach that combines "the literature on the long-term evolution of political cleavages with the more short-term strategic perspectives (...)”. Bremer (2017, p. 2) has, from a slightly different angle, argued that "(...) the problem with many (...) studies is that they examine party competition in a vacuum and ignore the role of contextual factors". Finally, Beramendi and his co-authors (2015) call for research that pays attention to the fact that the "strategic adaptation of actors and the institutional feedback from the context in which they operate mediate the ways in which political demands are actually articulated, and ultimately the responses in terms of political supply by collective actors and governments". 
In other words, scholars emphasize the context of party competition. The need to pay more attention to contextual factors stems from a simple observation: the degrees of freedom in strategic party competition are limited. As Kitschelt (2018) puts it:

If the convergence/competition argument (...) is correct, conventional parties could stave off the rise of radical right-wing parties by polarizing distributive conflict. So there must be "distal" causes for the established parties' relative convergence and proximity of positions on the economic and social policy dimension that then activate the "proximate" mechanisms facilitating radical right wing electoral success, when political demand conditions are ripe.

Kitschelt (2018), in other words, raises the question: if convergence in the socio-economic dimension causes enables radical right success, then why do mainstream parties not simply take more extreme positions in this axis, thereby increasing party system polarisation?

The argument we make in this paper is that the Eurozone crisis demonstrated the significance of European political-economic integration as a "distal" cause for the incapacity of mainstream political parties to take polarising positions on European distributive issues. We acknowledge that there are other causes, not least feedback effects from existing institutional arrangements and ideological legacies (Beramendi, Häusermann, Kitschelt, \& Kriesi, 2015). We, however, choose to emphasize the effect of political-economic integration, as a context factor that has not been exhaustively addressed in the literature. Recent contributions addressing the issue include Ward, Ezrow, and Dorussen (2011, p. 1227), who have argued that "integration into global markets and into the European Union (EU) constrains parties' ability to credibly differentiate themselves on economic issues". Hutter and Grande (2014) have argued that populism in domestic politics works as a constraining factor for national governments in EU-level decision-making. We argue, in contrast, that populism - radical right-wing parties included - may increase as a negative consequence of the constraining effect of economic globalisation and EU integration on national politics. That is, the loss of monetary - and economic - policy autonomy may produce a populist backlash in domestic politics.

In what follows, we first introduce our research design and methodology for the analysis of primary sources. We also discuss the limitations of our dataset. Thereafter, we introduce the Finnish case and discuss it in light of the relevant demand-, supply and context factors. We will emphasize the consensus among the mainstream parties on a pro-EU position as a facilitating supply-side condition; the deteriorating economic situation as a demand-side condition; and Finland's EMU membership as a key context factor. Finally, we present our analysis of the primary evidence from the public debate in the Finnish press.

\section{Research design: data and methods}

The object of inquiry in this paper is the politicisation of the Eurozone crisis in Finnish public debate. Following Dolezal, Hütter, and Wüest (2016), we have chosen to focus on newspaper data in order to capture the full variety of the debate in question. Our justification for this choice is as follows.

Politicisation can be conceptualised as "an expansion of the scope of conflict within the political system." More specifically, it entails the "expansion of debates from closed 
elite-dominated policy arenas to wider publics" (Statham \& Trenz, 2013, p. 3). Such expansion means two things. First, as contestation becomes public, actors will have to justify their issue positions to the audience, thus making them more explicit. Secondly, the "audience" may in fact participate in the debate. In short, the range of actors taking part in the debate will increase. Analysing public debates therefore offers a window of observation into the interactions between different speakers.

It should be noted that for the purposes of this article, analysis of party positions may have sufficed. The data was, however, originally collected as part of a larger project on the whole duration of the financial crisis (see Salo, 2017). The analysis of different events during the crisis, across countries, required a data collection strategy that would capture issue positions not only from political parties, but also actors such as banks, trade unions, EU officials and governments. Only some of the events during the crisis were dominated by parties.

The most important alternative data sources, such as party documents (e.g. manifestoes, available for example in the Comparative Manifesto data) or expert surveys only report party positions. More importantly, however, these data also involve a pre-determined categorisation of issues, which would not have been adequate for the purposes of this study.

In sum, as Dolezal, Grande, and Hutter (2016, p. 44) observe, “(...) mass media data allow us to examine the visibility of actors in a conflict, the specific issues addressed, the actor's issue positions and the way they justify these positions". Media data does inevitably have its shortcomings, as well. For example, media tends to give disproportionate space for established large parties, at the expense of minor or challenger parties. This is, to an extent, a problem for the article at hand, given our specific interest in the radical right-wing Finns Party. Indeed, only $3.4 \%$ of all claims in our data sample are by the Finns Party. Given this, we have also used posts from Ploki, the Finns Party's longterm chairman Timo Soini's blog, in assessing the party's position vis-à-vis the Eurozone's crisis management.

The data of this study consists of 1,183 core sentences, coded from newspaper articles from Finland's main national newspaper, Helsingin Sanomat. In Finland, the daily broadsheet Helsingin Sanomat has an exceptionally strong position in the national media field. Its circulation was 321828 in 2016, leaving the biggest competitors, Aamulehti and Turun Sanomat far behind.

The periods of observation are between April 26 and May 28 and October 17 and November 27, 2010. The periods correspond to the highly controversial EU-level decisions to extend emergence assistance loans to first Greece in May and then to Ireland, in November. The articles were sampled from the electronic archive of Helsingin Sanomat by using keyword strings. The keywords were related to the crisis (e.g. "financial crisis", "debt crisis") or to the actors we were interested in (e.g. "SDP", "Perussuomalaiset"). A maximum of 10 core sentences has been coded per article. The method we use is core sentence analysis (CSA), a form of relational content analysis. In CSA, the grammatical sentence of an article is reduced to its most basic "core sentence(s)" structure, which contain (s) only the subject, the object, and the direction of the relationship between the two (e.g. Kleinnijenhuis, de Ridder, \& Rietberg, 1997; Kriesi et al., 2012). This type of quantitative content analysis allows us to study both issue positions and salience. The direction between actors and issues is quantified using a scale ranging from -1 to +1 , with one 
intermediary position, 0. For example, the grammatical sentence "Party leader A rejects calls for leaving the Eurozone but supports a haircut on the country's debt" leads to two coded observations (Party A +1 Eurozone membership; Party A +1 haircut). For both events, we coded data for approximately one month surrounding the event, maximum 10 sentences per article.

In this paper, we focus on three variables: issues, actors and frames. However, given the rather strict guidelines in CSA for coding frames, ${ }^{2}$ most sentences do not include an explicit frame, and hence the amount of observations with frames is limited. ${ }^{3}$ Hence, a key part of the analysis has been the categorisation of issues. Here, our attempt has been to tease out the expected division of issues into socio-economic and socio-cultural, in order to assess the salience of the two issue types for different actors. This has, however, proven more difficult than we expected. The data we use was originally coded for a project on the Eurozone crisis, and therefore, socio-cultural issues such as immigration or minority rights were excluded by the selection of keywords.

However, as Bornschier (2018) has reminded us, socio-cultural issues include also questions of borders and boundaries, governance, law and rules. In our categorisation of issues (Table 1), particularly categories on "EU competences \& institutional reform" and "Domestic competences \& sovereignty" correspond to these types of issues. In other words, issues in these categories deal with the now politicised division of competences in the area of crisis management between the domestic and the EU-levels. These types of issues may also concern the question of who contributes and on what conditions to the EFSF/ESM, the rescue funds from which Greece, Ireland and Portugal were capitalised.

With regard to frames, a short word on categorisation is also in order. Below we will emphasize the shift from justice/market framing in the financial crisis to what we label "polity" framing in the Eurozone crisis. Justice frames in our typology refer to justification of claims by references to social justice, equality, morality, or for example the "public interest". In the financial crisis stage, for example, those opposing the bank rescue packages often referred to the moral hazard of bailing private sector firms out with tax revenues.

Polity frames, by contrast, justify positions by reference to territorially defined conception of justice. Claims framed in this way would refer to a policy being in the "national" or "European" interest, for example. If the binary opposition between social and market justice - whether a policy creates equality or whether it creates economic growth as the measure of its value - corresponds to the left-right division in politics, we can think of the polity-type of framing corresponding, rather, to the socio-cultural universalism-particularism axis in politics. Thought of in this way, what the Table 4 tells us is that in the

Table 1. Issues by event.

\begin{tabular}{lccc}
\hline & Greek rescue & Irish rescue & Total \\
\hline EU crisis management \& rescue measures & 39.6 & 33.8 & 37.6 \\
Banking rescues \& regulation & 19.6 & 15.9 & 18.3 \\
Conditionality \& principles of EU rescue measures & $\mathbf{1 3 . 1}$ & $\mathbf{1 7 . 1}$ & 14.5 \\
EU competences \& institutional reform & 11.4 & 5.5 & 9.4 \\
Domestic fiscal \& labour market policy & 7.3 & 11.1 & 8.6 \\
Domestic competences \& sovereignty & 3.3 & $\mathbf{1 4 . 1}$ & 7 \\
Domestic politics & 4.1 & 1.5 & 3.2 \\
Democracy, transparency \& social justice & 1.6 & 1 & 1.4 \\
& 100 & 100 & 100 \\
\hline
\end{tabular}


Eurozone crisis stage, political conflict moved from the socio-economic to the socio-cultural axis, or, at least, that the latter type of conflict gained more salience.

\section{Finland in the Eurozone crisis: mainstreaming right-wing populism?}

In this section, we introduce our case study, Finland, paying particular attention to the political and economic context in place, as the crisis hit. First, however, we will discuss the character of the radical right-wing Finns Party, as well as both internal and external changes that may have helped the party in 2010 to successfully influence the interpretation of the Eurozone crisis.

\section{Finns Party: a short history}

The Finns Party originates in 1950-60s agrarian populism, a response to social dislocations caused by rapid urbanisation of that period. The main party emerging from this populist wave, the Agrarian League, gained moderate electoral success, and even entered a coalition government with the Social Democrats, the Centre Party and the Swedish People's Party in 1983. Weakened by internal strifes, however, the party lost relevance and finally went bankrupt in 1995.

That might have been the story of Finnish populism, were it not for the young University of Helsinki graduate, Timo Soini. Soini had joined the Agrarian League in 1979 and was a keen admirer of its charismatic leader, Veikko Vennamo. When the League went bankrupt, Soini, with three other former party members, established the Finns Party in 1995.

The party's inception coincided with a wave of radical right mobilisation across Western Europe, and it was Soini's outspoken aim to bring the Finns Party closer to Scandinavian radical right parties, such as the Progress Party in Norway. Yet, at least up to and including the 2007 parliamentary election campaign, the legacy of agrarian "poverty populism" (Ylä-Anttila \& Ylä-Anttila, 2015, p. 87) remained prominent in the Finns Party.

According to Ylä-Anttila and Ylä-Anttila (2015), the party's ideology consisted of three main components: a populist defense of the common people against corrupt politicalecononomic elites; a left-wing economic discourse; and nationalism. As such, the party presented itself as the defender of common, poor (and rural) people against self-interested Finnish and EU-elites. The aim was securing the votes of the society's "most disadvantaged" and at inciting protest "from the margins of society" (ibid, p. 85). Nationalism manifested itself in two main ways. First, the Finns Party wanted to protect the Nordic model of welfare against attempts to cut it back via "various EU-led strategies" (Finns Party election manifesto, quoted in Ylä-Anttila \& Ylä-Anttila, 2015, p. 85). Secondly, it warned against Finland's "decreasing influence" in the EU, and advocated closely guarding the national interest in EU-decisionmaking. It was exactly these two features of Finns Party discourse - welfare chauvinism and EU-policy based on Finnish national interest that broke through in the Eurozone crisis debate, in 2010.

Later, nationalism became more prevalent in the Finns Party's ideology, particularly in relation to Jussi Halla-aho, who, in 2017, was to become the Finns Party chairman. Hallaaho first ran as a Finns Party candidate in 2007 parliamentary elections, but unsuccessfully. However, his blog, titled "Scripta, Writings from the sinking West" served as an 
online forum for Finnish anti-immigration activists. It was these activists who in 2008 established Hommaforum, an anti-immigration website and discussion forum, which became the base of the Finnish anti-immigration movement. (Ylä-Anttila, 2017)

Timo Soini was apparently at first reluctant to accept these more radical right-wing forces into his party (ibid). Yet, the electoral potential of the Halla-aho group eventually weighed more in Soini's reckoning. Indeed, several members of this group, former or current activists of the Hommaforum, ran for the Finns Party in the 2011 elections.

The result in the elections 2011 was, as the Figure 1 above indicates, a resounding victory for the Finns Party. Indeed, the electoral fortunes of the Finns and the Centre Party were turned upside down: the Centre Party's share of the vote collapsed to 15.8 whilst the Finns Party got 19.1, becoming the third largest party in parliament just after the National Coalition Party (20.4\%) and Social Democrats (19.1). In terms of voter volatility, the share of voters who had changed the party they voted was $32 \%$ in 2011 , the highest since year 1975, whilst in 2007, by contrast, it was only $20 \%$, the lowest in the observation period (Borg, 2011, p. 131). This indicates for us that the period between 2007 and 2011 was extremely important for the Finns Party's success, not least because of its role in the politicisation of the Eurozone crisis.

\section{Political-economic context in Finland}

In this section, we will discuss the political-economic situation in Finland when the crisis hit.

Economically, as a small, export-oriented economy, Finland was hit by the real-economic downturn that followed. This was combined with a structural crisis in the Finnish forestry sector and the decline of the telecommunications giant, Nokia. Together these changes meant that the share of industrial exports fell more in Finland than in any other OECD economy, over 100000 jobs were in these sectors, and, as a result of collapsing revenue from the trading sectors, public finances deteriorated. By 2015, debt to GDP ratio had risen to $63 \%$. The increased attention on public deficits became a powerful rhetorical weapon for the Finns Party. Fear of sovereign default was used both to justify austerity measures in Greece, Ireland and the other debtor states, as well as later to justify austerity measures at home. It now appeared entirely plausible to link together Finland's EMU membership, the shrinking public purse at home and the misfortunes of Greece and

VOTE SHARE OF FINNS PARTY, 1991-2015

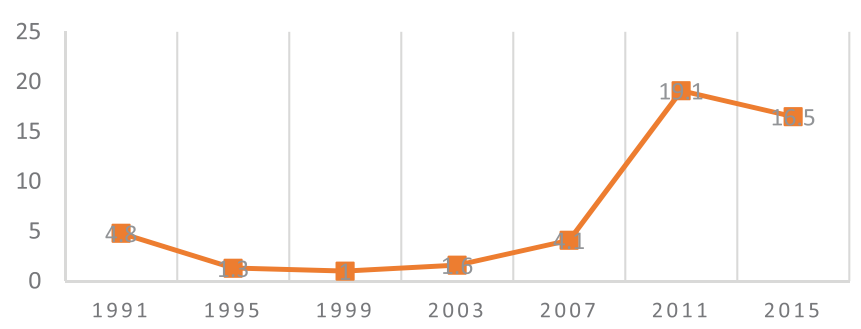

Figure 1. Vote share of the Finns Party, 1991-2015. 
others, in an argument that skilfully combined the defence of the Finnish taxpayer with anti-EU, anti-elite claims.

Politically, Finland had from 2007 to 2010 been governed by a centre-right majority government composed of the Centre Party (Keskusta), the National Coalition Party (Kokoomus), the Swedish People's Party (RKP) and the Greens (Vihreät). The coalition was led by largest party, the Centre Party, which had won $24.7 \%$ of the vote in 2007 . The Prime Minister was Centre Party leader Matti Vanhanen, and the National Coalition Party leader Jyrki Katainen served as Minister for Finance. The opposition parties were the Social Democratic SDP (24.5\% of the vote in 2007), Left Alliance (Vasemmistoliitto), Christian Democrats (KD) and the Finns Party (Perussuomalaiset, PS), which had in 2007 only secured $1.6 \%$ of the vote. In June 2010, however, PM Vanhanen had to resign and was replaced by Ms. Mari Kiviniemi as party leader and as Prime Minister. Vanhanen's departure was due to a major corruption scandal, in which the Centre Party and Vanhanen himself were heavily implicated. In short, as of year 2008, it was gradually revealed that a group of wealthy businessmen had been financing the Centre Party's 2007 election campaign in exchange for political favours, such as planning permits. Vanhanen himself had to confront several claims of personal involvement, but was not criminally charged. The corruption scandal was the single most important domestic political reason for the subsequent rise of the Finns Party in the 2011 elections. It enabled the Finns Party to use one of its preferred frames, the common people against corrupt political elites.

Yet, the Eurozone crisis added to the jackpot for the Finns Party. As was discussed above, mainstream parties converging on an issue dimension will increase the opportunities for challenger parties to mobilise on that dimension. Finnish EU policy was characterised by a pro-EU consensus in the pre-crisis decade. As Jokela (2015, p. 26) observes, Finland has often been characterised as the most integrationist, constructive Nordic member of the EU. Finland joined the Union in 1995 without any major reservations or opt-outs - unlike Denmark, for example - and participating in all the Union's core projects, such as the EMU and Schengen, has been important. It also has not subjected any of the Amsterdam, Lisbon or Nice Treaties to popular referenda, as did many other member states. A key consideration for Finland has been security-related. Participating fully in European integration has meant a decisive step away from the "grey area" between the East and West - a position Finland found itself in the post-war years - and anchored the country as a firm member of the Western European sphere of influence. Even though joining the EMU in 1999 was, at the time, recognised as economically controversial, the geo-political benefits overrode other concerns.

Grönlund and Westinen (2011, p. 168) observe that European integration long divided the Finnish parties, but, since the early 2000s, all the mainstream parties have increasingly converged on a pro-EU position. Similarly, Jokela (2015, p. 26) characterises the Finnish pre-crisis situation as a "pervasive national consensus" on the benefits of EU integration. Yet, Grönlund and Westinen (2011, p. 172) also observe that $25 \%$ of voters who responded to the election survey in 2011 supported the statement that "Finland should leave the EU". This was the niche that the Finns Party took advantage of. Borg (2011, p. 201) shows that for $38 \%$ of Finns Party voters, decreasing Finland's commitment to EU integration was a the decisive factor behind their voting decision. In the political supply-side, EU criticism was the sole domain of the Finns Party: no other party would, prior to the crisis, take 
polarising positions in this issue, and the Finns Party was willing to cater to this mismatch between the voters and mainstream parties.

Before moving on to the actual analysis, let us look at the main context factor that conditioned Finland's politics in the crisis: the EU's common policy response. Hobolt and Tilley (2016, p. 971) have observed that the "emergency politics of the crisis dramatically limited the political choices available to citizens". We do not focus on citizens' choices, but those available for parties. We find them similarly constrained. This has to do with the character of the political conflict the crisis invoked, which, as Salo (2017, p. 38) has argued, represented a "hybrid" political conflict, including both a domestic and an international dimension. Whilst many political issues - such as trade or climate policy include an international aspect, the Eurozone crisis was new in one key sense: it removed redistributive policy, taxation and public spending, from being a prerogative of national governments. As Bechtel, Hainmueller, and Margalit (2014, p. 835, emphasis added) put it, the EMU's financial assistance mechanisms represented a "major new form of international redistribution". In other words, when governments in some EMU member states decided to spend tax contributions of their citizens to assist failing banks and sovereigns of other member states, taxation and redistribution ceased to be purely domestic matters.

Bringing tax-and-spend-policies to the realm of EU decisionmaking crystallised the importance of the EU constraint in domestic politics. Trade and climate policy are areas largely perceived as belonging to the realm of international politics; redistribution has been perceived as the realm of domestic partisanship, where citizens hold parties more directly accountable for executing their mandate. In the crisis, however, literature indicates that party behaviour was less determined by voter preferences than it would usually be, and more by the perception of "there was no alternative" (Armingeon, 2012; Pontusson \& Raess, 2012).

Bechtel et al. (2014, p. 854) observe that "public opinion on the EU bailouts is widely regarded as a major constraint on government actions in dealing with the crisis". We know indeed that public opinion across European countries was firmly against the bailouts, but we also know governments executed the bailouts nevertheless. Hence, our analysis focuses on the political game that appeared around justifying the choice to participate in the financial assistance to the public. We maintain that it was the dynamic between adverse public opinion and the perceived lack of alternatives due to constraints imposed by EMU membership, that produced the politics of the crisis in Finland.

\section{The Eurozone crisis in Finnish Public Debate, May and November 2010}

Let us begin the analysis with a short detour into the debate on the financial crisis, which broke out in fall 2008. At this point, the crisis concerned a massive regulatory failure of financial institutions. That is: a problem of private sector mismanagement, not apparently related to public finances at all.

The crisis began in effect on 15 September 2008, when the United States government decided not to save the investment bank Lehman Brothers from bankruptcy. The fall of Lehman sent a shock wave to the financial markets, and in the subsequent weeks and months, many banks across the Atlantic were buffered with public money. Finland 
remained, at the outset, at the margins of the financial turmoil. Finnish banks were robust and not exposed to the US derivatives markets.

Finnish policymakers could therefore afford to remain moralistic on the justification of saving banks with public money:

Private enterprises that have got themselves into trouble should not be saved at any cost. Such behaviour is mismanagement of taxpayers' money. We should, rather, keep a cool head here. (Minister for Finance Jyrki Katainen (Kok), Helsingin Sanomat, 9 October 2008).

In a comprehensive study of the public debates on the Eurozone crisis, Salo (2017) has demonstrated how the framing of the crisis changed from the financial to the Eurozone crisis stage. In the financial crisis, so-called justice frames - that is, frames concerning social justice, public interest, morality - made up $28.9 \%$ of all frames, whereas so-called polity frames, concerning justice based on territorial considerations, such as national or European interest, only $7.8 \%$. In the financial crisis, the debate pitted states and markets against each other, and debates concerned the moral hazard spending public funds to shore up private actors, who should have hedged for market risks. The prospect of a conflict between different peoples seemed still distant:

The IMF and World Bank meetings over the weekend made it clear that "we're all in the same boat and united, we shall tackle this crisis", said President Bush. (US President George W. Bush, Helsingin Sanomat, 9 October 2008)

Policy responses were also directed at private sector mismanagement. Policymakers did not hesitate to draft ambitious plans for regulatory reform, to ensure the financial havoc would not be repeated (Helleiner, 2012). What happened? Coming to fall 2010, the perception of the crisis had changed almost entirely.

While memory of the abyss was still fresh, demands and blueprints for 'reform' to protect the world from a replay abounded (...) half a decade later hardly anything has come from them. In the meantime, the financial industry, where the disaster originated, has staged a full recovery: profits, dividends, salaries and bonuses are back where they were (...). (Streeck, 2014, p. 38)

As Helleiner (2012) observes, whilst the financial reform agenda resulted in some significant outcomes, such as the Basel III revision of liquidity requirements for banks, as a whole it was diluted by the inability of governments to agree on a set of reform measures to suit their respective economies. States were dependent on financial markets, each in their own particular way.

As of 2010, the epicentre of the crisis moved to Europe. It was in the European Monetary Union (EMU) that the burdens of the banking rescue measures for sovereign balance sheets materialised in the most drastic manner. States everywhere were dependent on the health of their banks: in the Eurozone, it turned out, states were also dependent on the health of banks in the other Member States. The Eurozone crisis crystallized the co-dependency of its constituent economies and demonstrated the practical difficulties of deep financial and economic integration without adequate political institutions to support it. It also demonstrated the reluctance of Member State governments to give up sovereignty to build such institutions.

The Eurozone crisis began with Greece. In spring 2010, it became clear that market pressure on Greek sovereign bonds had increased to proportions, which the PASOK 
government could not manage by itself. It had attempted to calm the markets with austerity measures, with little result. In May 2010, EU leaders approved a financial assistance programme, where Eurozone Member States together with the IMF would provide Greece with financial assistance in return for fiscal austerity and structural reforms. Ireland followed suit in the fall of that same year. Facing an apparent contagion effect from Greece, markets showed increasing mistrust in Ireland's ability to service its debt towards late 2010, causing Irish bond spreads to hike. As had been done by its Greek counterpart, the Irish government initially responded with a domestic austerity plan the National Recovery Plan (NRP) - that included proposals for $€ 15$ billion of austerity measures on top of the $€ 30$ billion already implemented. But as with Greece, markets did not trust the firepower of the Irish government alone. The bailout loan finally agreed with the EU-IMF-ECB troika in November 2010 was circa $€ 85$ billion in size and came, as in the case of Greece, with strict conditionality.

This was the context in which the political debate which we analyse below took place. Its tone had taken a sharp turn from George W. Bush's "we're all in this together"- frame.

According to [Prime Minister] Kiviniemi, Finland only considers one question in the negotiations: what's in it for Finland. (Helsingin Sanomat, 26 November 2010)

In the Table 1, below, we show the distribution of main issues in the debate across the two events, the Greek and Irish rescue packages. Banking issues no longer dominate the agenda. The categories we wish to highlight here are particularly the two categories concerning the division of competences between the domestic and the European levels. The debate had now moved to concern the procedures and principles of dividing sovereignty between the levels of policymaking in the EU. And we use the word sovereignty to highlight the crucial differences between the financial assistance decisions from all other policy decisions previously made in the EU context: this time, the "common European interest" required spending domestically collected tax revenues to shore up other constituent economies. This was an exercise in ad hoc federalism, to which Member States were poorly prepared. In the process of hasty institution-building, governments were driven by consideration of the national interest, as the quote above from Prime Minister Mari Kiviniemi makes clear.

In Table 2 below, we highlight another feature of the Eurozone crisis debate that sets it apart from what we know of the financial crisis stage (Salo, 2017).

In the financial crisis, Finnish party actors made as few as $2.8 \%$ of all claims in the debate. Their share had now risen to $24.6 \%$. This indicates (following Hutter et al., 2016) an increase in politicisation. Finland was no longer on the outside, but had to assume, as an EMU Member States, full responsibility for assisting Greece, Ireland and other Member States whose situation was threatening the currency bloc.

Who led the politicisation? In Table 3 below we show the shares of different parties of all the claims made by domestic party actors in the debate. We see that the shares of opposition parties SDP and PS (Finns Party) are disproportionately large in comparison to their share of the vote in 2007 (SDP 21.4; PS 4.7), whereas that of the main party of government, Keskusta (Centre Party) is surprisingly low (vote share in 2007 was 23.4). This is not surprising as such: we would expect opposition parties to shout loud against government policy. It does tell us, however, that the Finns Party and the Social Democratic SDP were the key actors in the politicisation of the crisis. Moreover, as we see below, the two ideologically distant parties found each other in surprising ways in the debate. 
Table 2. Selected actors by event.

\begin{tabular}{lccr}
\hline & Greek rescue & Irish rescue & Total \\
\hline Foreign executive/government & 16.7 & 43.6 & 26.1 \\
Nat. political party & $\mathbf{2 8 . 4}$ & 17.6 & 24.6 \\
Nat. executive/government & 20.3 & 16.9 & 19.1 \\
European institutions & 12.5 & 11.6 & 12.2 \\
Nat. business & 7.8 & 0.2 & 5.2 \\
Foreign scientists/experts & 2.7 & 1.7 & 2.4 \\
Nat. interest groups & 2.5 & 1.9 & 2.3 \\
Nat. scientists/experts & 3 & 0.5 & 2.1 \\
Foreign interest groups & 2.6 & 0.2 & 1.8 \\
Foreign political party & 1.8 & 0.7 & 1.4 \\
& 100 & 100 & 100 \\
\hline
\end{tabular}

In Table 4 we show the distribution of frames in the two events. As was discussed above, social justice and moral hazard were prominent ways of framing the crisis in the financial stage of it. No longer so. In the Eurozone crisis polity frames, referring to territorially defined ways of conceiving justice, took prominence. That is: arguments were framed based on the notion that action would be for or against the interests of "Europe" or "Finland". The community to which justice arguments - which frames, ultimately, are - referred to had become defined in terms of territorial borders. This is the change in the presentation of the crisis, which we wish to highlight. That parties such as the Social Democrats or the Left Alliance were ready to adopt such mode of justification represents a significant departure from their core ideology, which is based on international solidarity.

In Table 5 below we break down the distribution of issues based on speaker category. ${ }^{4}$ This table serves to illustrate the position of the Finns Party (PS) as compared to all the other parties. As we discussed above, one supply-side factor underpinning the success of the radical right is a convergence of mainstream parties on a given issue dimension. In this table, we see that the main alternative to the Greek rescue package, sovereign default and leaving the Eurozone, was a salient issue only for the Finns Party, and to a much lesser extent, to the Left Alliance. The other parties were constrained by the proEU "pervasive consensus" (Jokela, 2015) in Finland and could not readily abandon that position.

In the analysis below we illuminate these arguments with quotes from the newspaper debates. We focus on, first, the policy options available in the Greek and Irish crises, secondly, casting blame on the crisis and, third, the position Finland should take in the negotiations and the conditions under which Finland should participate in the rescues. Our argument is that faced with the perceived inevitability of deferring to market discipline,

Table 3. Claims by Finnish parties.

\begin{tabular}{lc}
\hline Party & $\%$ \\
\hline Kokoomus & 30.3 \\
SDP & 27.1 \\
Keskusta & 15.8 \\
Perussuomalaiset & 7.4 \\
Vasemmistoliitto & 7.2 \\
Kristillisdemokraatit & 2.9 \\
Vihreät & 1 \\
RKP & 0.2 \\
\hline
\end{tabular}


Table 4. Frames by event.

\begin{tabular}{lccr}
\hline & Greek rescue & Irish rescue & Total \\
\hline Economic growth/stability & 20 & 28.1 & 22.8 \\
National interest/sovereignty & 19.3 & 17.1 & 18.6 \\
European interest/stability & $\mathbf{2 1 . 9}$ & 9.8 & 22.8 \\
TINA & 14.9 & 2.4 & 10.6 \\
Financial stability & 7.1 & 13.4 & 9.3 \\
Morality/justice & 9.7 & 6.1 & 8.4 \\
Democracy/transparency & 3.9 & 13.4 & 7.2 \\
Procedural & 2.6 & 4.9 & 3.4 \\
& 100 & 100 & 100 \\
\hline
\end{tabular}

and the impossibility of breaking away from the pro-EU fold, the mainstream parties resorted to framing the crisis as one pitting the parsimonious Northern and the spendthrift Southern states against each other.

As the Greek crisis broke out, the preferred course of action was not clear to policymakers. Just as policymakers had doubted the desirability of bailing banks out in fall 2008, they now doubted the morality of helping Greece. The fringes of the party system, Left Alliance and the Finns Party took the most drastic positions here. The Finns Party advocated Grexit, whereas the Left Alliance proposed debt haircuts: essentially, losses for private investors. In Table 5 we saw that the issue of conditionality for private sector (bank) rescue measures was most salient for the centre-left parties, the SDP and Left Alliance, whereas debt default and Grexit were mostly put to the agenda by the Finns Party.

What to do? First, Greece must be pushed out of the EMU and the drachma be devalued by $30-40 \%$. Then, the EU must be scaled back to a free trade zone. (Chairman Timo Soini (PS) in Ploki, 2 May 2010)

Chairpersons of the Left Alliance and Finns Party criticize the proposal to help Greece. According to Paavo Arhinmäki [Chairperson of Left Alliance], the Left Alliance does not accept the Greek aid package and does not believe the package will necessarily pass in Parliament. Arhinmäki thinks that former Greek governments have deliberately deceived their peers and this deception must be brought fully out in the open before such aid can even be thought of. (Helsingin Sanomat, 3 May 2010)

We must reduce Greece's debts and not only move the debts around to new payers, us. That way we can also reduce problems caused by an "internal devaluation": increase in unemployment, wage cuts and major social security cuts. (Former MEP Esko Seppänen [Left Alliance], Helsingin Sanomat, 4 May 2010)

The government, however, had to joggle between pressures from the domestic parties, EUlevel peers, and the markets. Market actors had made their position clear: governments

Table 5. Issue salience by selected actors (\% of all claims by actor).

\begin{tabular}{lcccccc}
\hline & Gov FIN & Kesk & Kok & SDP & Vas & PS \\
\hline Conditionality of EZ rescue packages & 19.4 & 5.2 & $\mathbf{2 6 . 4}$ & 5.3 & 2.9 & 0 \\
Conditionality in bank rescues & 3.2 & 2.6 & 8.1 & $\mathbf{1 3 . 6}$ & $\mathbf{1 1 . 4}$ & 0 \\
Debt restructuring, defaults & 0 & 0 & 5.4 & 2.3 & 5.7 & $\mathbf{1 6 . 7}$ \\
EZ rescue packages & 41.9 & 50.7 & 30.4 & 41.7 & 27.3 & $\mathbf{5 7 . 1}$ \\
EU coordination \& competences & 25.8 & 2.6 & 3.4 & 1.5 & 0 & 16.7 \\
Domestic coordination \& competences & 3.2 & 3.9 & 0 & 6.8 & 0 & 0 \\
Democracy \& transparency & 0 & 1.3 & 0.7 & 1.5 & 8.6 & 5.7 \\
\hline
\end{tabular}


must step in with considerable sums to guarantee Greece's debts. Any talk of debt haircuts or Greek default would only make matters worse.

"The risk of a Greek default has significantly increased in the eyes of financial markets. One way of calming down the markets would be to secure Greece's ability to service its debts for a much longer time than the 45 billion aid package will do", says the Pohjola Bank analyst, Robert Liljequist. (Helsingin Sanomat, 29 April 2010)

In the space of two years, policymakers indeed increased the lending capacity of EFSF, later ESM, seven-fold, to $€ 770$ billion. Minister for Finance Jyrki Katainen acknowledged that in principle, restructuring Greece's debts was a good idea, but for fear of market reactions, this was simply off the table. He then justifies this position by arguing that the stability of the currency bloc will serve Finland's interests rather than rocking the boat by forcing debt haircuts to investors.

Katainen assured that the government had carefully weighed the interest of the Finnish taxpayer. The worry is that a Greek default would increase the risk of a new recession in Europe. "It's either rescue or recession", Katainen quoted a highly esteemed official from the Ministry for Finance. (Helsingin Sanomat, 4 May 2010)

Katainen thought that restructuring was a good idea as such, if only it were possible in real life (...) debt restructuring may be spoken of in conjunction with future assistance loans. According to him [Katainen] right now it is impossible to negotiate with the markets about current problems. (Helsingin Sanomat, 19 November 2011)

The kind of "rescue or recession"-rhetoric, as in the first quote above, came to crystallize the official government position on the Greek and Irish rescue packages. We have to participate, lest markets will wreak havoc and the national economy will collapse.

Pekka Ravi (Kok) thinks we face the same choice as Odysseus when he met the sea monsters Skylla and Kharybdris: the options are complete disaster or a partial rescue. "Plague or Cholera", echoed Hannes Manninen of the Centre party." (Helsingin Sanomat, 5 May 2010)

Hence, in the Greek crisis, TINA (There Is No Alternative) was established as the common frame of reference (see Table 4). Now, as their space for action appeared thus constrained, policymakers were eager to look for culprits. Here we find another important difference between the mainstream and the Finns Party. The Finns Party politicians cast blame on the European Union and domestic political elites:

The European Union gets what it has deserved. Despite years of rhetoric about transparency, it has endorsed and covered up lying and deception. (Timo Soini, Chairperson of the Finns Party, Helsingin Sanomat, 27 November 2010)

Critics of the EU and the Euro have been ridiculed, also in Finland. Nobody laughs anymore. The next step, I am sure, is that those who warned [of the EU/euro], will be labelled irresponsible besserwissers. The ordinary folks only hear one thing: that there is no alternative but to guarantee and ultimately pay the debts of Eurozone countries. No wonder some people speak of a "coalition government of old [mainstream) parties". (Timo Soini, Chairperson of the Finns Party, Helsingin Sanomat, 27 November

Pentti Oinonen found culprits also in Finland. "Why did you just silently watch when they (the Greeks) were lying", he said, looking at the Ministers. "The truth is that Finland cannot save the whole world", he said. (MP Pentti Oinonen, Finns Party, Helsingin Sanomat, 5 May 2010) 
This clearly was a prerogative of a fringe party that had never been in governing position. For the government parties, criticising the elites they themselves were part of was impossible. They therefore cast the blame on the Greek people and policymakers.

According to Arto Satonen (Kok) we should remember, however, that Greece has lived beyond its means. In other words, ordinary voters should have demanded budgetary discipline from their politicians. (Helsingin Sanomat, 5 May 2010)

The Minister for Finance Jyrki Katainen (Kok) announced right away that culprits can only be found amongst the Greek people. He searched for culprits amongst irresponsible politicians of various partisan colours. (Helsingin Sanomat, 5 May 2010)

After the unavoidability of the rescue packages had been established as common ground, another topic of debate concerned burden sharing in the costs of the rescue packages. This was particularly the case in the debate on Ireland, where the crisis - and what was being saved - was much more clearly about the banks. The left-opposition parties SDP and Left Alliance took positions in accordance to their ideology, promoting burden-sharing by private market actors.

Banks and speculators must shoulder their responsibility for assisting the countries in crisis. A bank levy must be adopted in the Eurozone, and Finland must be proactive in pushing forward a global FTT, says Urpilainen. (Chairwoman Jutta Urpilainen (SDP), Helsingin Sanomat, 21 November 2010)

Also Paavo Arhinmäki, leader of the other opposition party Left Alliance, demanded that banks pay for their own risks. (Helsingin Sanomat, 21 November 2010)

Market actors contrasted the SDP/Left Alliance position by arguing that overregulation such as the Financial Transaction Tax promoted by the SDP - would have negative market consequences. Notably, the chairman of the Helsinki Stock Exchange equates his antiregulation position with the national Finnish interest in the below quote.

General Director of OP-Pohjola-group, Reijo Karhinen, fears that the financial and economic crisis may be followed by a regulatory crisis, due to the excessive constraints being imposed on the banking sector. Karhinen said he was truly worried of overregulation. (Helsingin Sanomat, 6 May 2010)

If the EU would, as Urpilainen hopes, act as a world leader in the FTT issue, trade in liquid Finnish stocks would easily slide beyond the reach of Finnish small investors, Finnish regulator, and the Finnish tax system. (Lauri Rosendahl, Nasdaq OMX Helsinki, Helsingin Sanomat, 28 April 2010)

Finance Minister Katainen and EU Commissioner Olli Rehn dared barely to hope that markets would participate in burden-sharing.

He [Katainen] hopes that those who have in the last weeks invested, in the hope of high yields, would in some way participate in the arrangements, alongside Eurozone taxpayers. (Helsingin Sanomat, 8 May 2010)

According to [Olli] Rehn, banks shall participate on a voluntary basis. "I have noted that private banks have already move to this direction”, formulated Rehn. (Helsingin Sanomat, 4 May 2010)

As we saw in Table 5 above, the issue of conditionality in banking rescue measures was not a particularly salient one for the centre-right parties Kokoomus or Keskusta, which 
Finance Minister Katainen and Commissioner Rehn represented. Rather than pushing sanctions for banks and private investors - something they deemed impossible, apparently - the centre-right politicians chose to emphasize sanctions for the Member States in the financial assistance programmes.

When it came to the power of policymakers over private sector actors, as the Irish economist Morgan Kelly (Vanity Fair 2011, emphasis added) succinctly put it, in the crisis these executives essentially forgot that

(...) the government has certain powers (...) You can conscript people. You can send them off to certain death. You can change the law.

What then should be the position Finland takes in the negotiations over a rescue package, if such an outcome cannot be avoided? Here what we labelled above as "polity" framing (Table 4) really took off. Policy was now evaluated based whether it served - or did not serve - justice defined in terms of boundaries and identity. That is, whether it served "European" or, as in the quotes below, Finnish "national" interest. We start seeing how what essentially was a redistributive debate became framed in socio-cultural terms.

Just like Germany, Finland should wake up to defend its own interests - otherwise we will end up naïvely paying for the recklessness of others. (MP Marjo Matikainen-Kallström (Kok), Helsingin Sanomat, 4 May 2010)

Judging by assets, Greece is by no means poor - it is just unwilling and unable to organise its possessions, just like a relative in need of money, asking for a loan while simultaneously holding on to significant wealth. (MP Marjo Matikainen-Kallström (Kok), Helsingin Sanomat, 4 May 2010)

Government policymakers then hastened to make assurances that their negotiating position was tough and the national interest their guiding principle.

Finland advocates cuts to EU-funds for the spendthrift countries, in order to put political pressure on governments. This threat would not necessarily require changes in the Treaty. Finland is, however, ready for Treaty changes, even if this would take years. (Helsingin Sanomat, 8 May 2010)

Finland represented the strictest approach in Europe in the loan negotiations, according to Katainen. "We got what we wanted", said Katainen. (Helsingin Sanomat, 4 May 2010)

Particularly references to how failure to participate in the package would lead to drastic recession at home, were popular among government politicians. Prime Minister Kiviniemi even invokes the memory of the 1990s recession, a national trauma, to justify the government's position.

In Finland, Prime Minister Mari Kiviniemi defended the loan package by saying that helping Ireland sustains the development of the Finnish economy and Finnish jobs. (Helsingin Sanomat, 23 November 2010)

According to [Prime Minister] Kiviniemi, Europe could end up as Finland in the 1990s, if Ireland was not helped. "Banks are not saved for the sake of saving them; rather, if they would fall, there would be great damage. Businesses would go down, and many would lose their homes", said Kiviniemi. (Helsingin Sanomat, 26 November 2010)

As we argued above, a feature that set the Eurozone crisis debate apart from previous European policy debates was how taxation and redistribution were now "Europeanized", 
for example in the sense of Irish taxes or Greek pensions being discussed in the Finnish public arena.

Germany and Finland are raising pension ages, whereas in Greece, workers can get a pension at an exceptionally low age. (MP Marjo Matikainen-Kallström [Kok], Helsingin Sanomat, 4 May 2010)

Particularly the pivot of the social democratic SDP is interesting. The party now justified demands for more market regulation and private sector burden sharing - as higher corporate taxation, below - with the Finnish national interest. "We Finns pay for your corporate-friendly tax policy, and that's not acceptable" is the message of SDP leader Eero Heinäluoma to Ireland, below. Again, we wish to emphasize how the notion of justice defined in terms of boundaries and (national) identity, raised its head (see Table 4). In Table 4 we saw that in the Irish rescue event, the three most prominent frames were national identity, financial stability and economic growth. What we see in the quotes below is how the Social Democratic party combined the three in their rhetoric.

The [SD] parliamentary group leader Eero Heinäluoma cut corners and said that Finland has to maintain high taxation to compensate for Ireland's $12.5 \%$ corporate tax rate. According to him Finland, and the EU, should demand that Ireland raise the rate in exchange for help. Now, Ireland just makes its competitors to raise taxes. (Helsingin Sanomat, 19 November 2010)

Social Democrats see Ireland continuing, on European taxpayers' money, as a country of low corporate taxation, as unsustainable: this would only sustain tax competition that is hazardous for welfare states. (Helsingin Sanomat, 23 November 2010)

The new Social Democratic frame, economic justice defined in terms of national interest, was crystallized in their demand for "collateral" in exchange for Finnish participation in the rescue packages. Collateral, in this context, meant explicit, material guarantees that Finland would be paid back its money in the event of a debt default by Greece, or any other country that Finland had assisted.

And like all Social Democrats, she [Ms. Urpilainen] asked [the Minister] about conditionality. She claimed the government had in the spring been deaf to the demands by SDP for collateral. She asked the Minister for Finance to be persistent now, that he had finally taken the SD's position in the issue. (Helsingin Sanomat, 19 November 2010)

For the centre-right Finance Minister Katainen the issue was awkward. The collateral idea was essentially a way of the SDP to justify Finland' s participation in the EFSF/ESM to its electorates. Arguably, most policymakers must have know it had little practical value. However, failure of any one Member State to pass the necessary legislation through its parliament could have compromised the whole rescue operation in question. Policymakers were therefore under severe pressure to push the decision through at the national level, and Minister Katainen therefore had to at least pretend to have negotiated on the collateral at the EU level.

I haven't yet got neither a thumbs up, nor a thumbs down, said Katainen. Other countries have thought the idea is "interesting". (Helsingin Sanomat, 16 November 2011)

He [Katainen] said he had fiercely and persistenly demanded collateral from Ireland, but was left alone. "I did not get support from anyone in Europe". (Helsingin Sanomat, 19 November 2010) 
There was one group of Finnish politicians, however, who saw the situation beyond the nationalistic lens: MEPs. Long-term SDP MP and MEP, Liisa Jaakonsaari explicitly criticises her own party for using the crisis for electoral ends in a populist manner.

If I were the leader of SDP, I would not take Ireland as a weapon in domestic politics. We have to remember that the Social Democrats advocated both Finland's EU and EMU membership from the opposition. Jaakonsaari regrets particularly the Finnish demands that Ireland raise its corporate tax rate. This would be poison for Ireland. There is now an atmosphere of punishment in Finland (MEP Liisa Jaakonsaari [SDP], Helsingin Sanomat, 24 November 2010)

She [Pietikäinen] thinks that we should be talking more about financial regulation. "With proper regulation, the Greek and Irish crises could have been avoided." (MEP Sirpa Pietikäinen [Kok], Helsingin Sanomat, 24 November 2010)

The demands for collateral are shadow-boxing, and should hardly be sustained, Pietikäinen said on Tuesday. (MEP Sirpa Pietikäinen [Kok], Helsingin Sanomat, 24 November 2010)

The rhetorical pivot of SDP demonstrates how difficult it was for policymakers to think outside the national box, and to consider at a European-systemic level, which the best response might be. Hence was born the punitive political climate that defined the policies of crisis management and had also very practical policy implications for countries such as Greece and Ireland, locking them to austerity for years to come.

\section{Conclusion}

In this article, we set out to examine the politicisation of the Eurozone crisis in the Finnish public debate. We argued that the political conflict that emerged in the crisis had the distinctly new feature of combining socio-economic questions - taxation and redistribution with socio-cultural questions of borders and boundaries. In fact, one could characterise the crisis as a distributive conflict cast in socio-cultural terms. We were interested in the role of the radical right Finns Party in advocating this framing and the extent to which mainstream parties had also adopted it. Our analysis took into account the relevant supplyand demand-side factors in the politicisation of the crisis. On the demand-side, we expected the economic downturn to have increased dissatisfaction with the established parties among the electorates, increasing the momentum for the Finns Party. On the supply-side, we emphasized the consensus on a pro-EU position amongst all the mainstream parties, enabling the Finns Party to position itself alone as the party of opposition.

One important contribution is that we also observe the context in which strategic party competition took place. In other words, we look for the reasons for why that mainstream parties would not simply re-politicize the EU issue dimension, by taking more radical positions on it, if they knew that not doing so would cost them votes? We argue that European political-economic integration is a factor that constrains the ability of mainstream parties to take polarising positions on a number of issues. In the Eurozone crisis such issues also included domestic tax-and-spend policies. Because market reactions to financial difficulties in Member States such as Greece and Ireland threatened the stability of the whole currency zone, governments deemed bailing these states and their banks out with public funds as an inevitable course of action. Globalisation and European integration have long restricted the course of action available for national-level policymakers: The Eurozone crisis took this constraint to a new level. 
Our analysis reveals that issues regarding the division of competences between the EU and domestic levels took precedence in the Eurozone crisis, over banking policy issues that had dominated the financial crisis. This had to do with the fact that taxation and redistribution, both in the debtor and the creditor states, were effectively Europeanised in the crisis. The EU was institutionally poorly prepared to organise international redistribution, which left the effort for the reluctant Member States. We then find that the debate in Finland was highly politicised, when measured with the proportion of domestic political parties as claims-makers. The opposition parties, social democratic SDP and the Finns Party, were disproportionately prominent debaters as compared to their share of the votes. In terms of frames, we find that the type of market vs. social justice framing that characterised the financial crisis now gave way to a mode of justification based on territorial notions of justice. That is: arguments were now increasingly framed as serving the "European" or the "national" interest. Finally, when looking at issue salience across parties, we find that the fringes of the party system - the Left Alliance but particularly the Finns Party - stood for the more radical alternatives of crisis resolution, whilst the centre was constrained to put forward any anti-systemic proposals, such as Grexit or bond haircuts.

Looking more in detail at how the fringe parties', especially the Finns Party's framing differs from that of the mainstream, we find a key difference. The Finns Party used an antiestablishment framing, casting blame on the EU as a whole as well as domestic political elites. Such framing was hardly available for the mainstream parties, who were part and parcel of that elite. As our analysis shows, the governing parties perceived other courses of action except supporting Greece and Ireland with public money impossible, for fear of adverse market reactions. They had to publicly support the EU's chosen policy response, given that it was unanimously decided upon in Brussels. We argue that ultimately it was the strict constraints imposed on policymakers by the necessity of acting in a certain manner, lest the EMU and its constituent economies face an existential crisis, that brought on the punitive political climate where the national interest appeared as the guiding principle of all policymaking. Had the EU been better prepared to institutionally handle cross-border fiscal transfers, the outcome may have looked different. Of course, the fundamental economic imbalances in the Eurozone that gave rise to the crisis in the first place were not fully recognised until after the crisis, and hence no need to develop such mechanisms existed.

We conclude by reiterating our position that per contra Hutter and Grande (2014), who have argued that populism in domestic politics works as a constraining factor for national governments in EU-level decision-making, that populism at the national level may increase as a negative consequence of the constraining effect of economic globalisation and EU integration on national politics - and that is precisely what occurred in the crisis.

\section{Notes}

1. Our data is limited to events in year 2010, and hence showing change in party positions across time is challenging. We will, however, refer to data gathered by Salo (2017) on the 2008-9 financial crisis stage, in order to make comparisons across time.

2. In CSA, frames are only coded if the sentence includes an explicit justification for the issue position taken. In newspaper articles, this is mostly not the case. 
3. The low cell frequencies are also the reason we do not present a more detailed version of Table 4, that is, frames by actor.

4. We do not present a similar table for frames, because - though this would have been illuminating - the cell frequencies in such table would have remained too low. This is due to our limited sample size, but most importantly to the rigid way of coding frames in CSA, which we discuss in the methods section above.

\section{Disclosure statement}

No potential conflict of interest was reported by the authors.

\section{Funding}

The authors greatly appreciate funding from the Swedish Science Foundation (Vetenskapsrådet).

\section{Notes on contributors}

Sanna Salo is a post-doctoral fellow at Stockholm University. She works in the fields of political sociology and political economy, particularly that of the Europe.

Jens Rydgren is Professor of Sociology at Stockholm University. He is working within the areas of political sociology, ethnic relations, and social networks. Among his recent books are Class Politics and the Radical Right (2012, Routledge) and The Oxford Handbook of the Radical Right (2018, OUP).

\section{ORCID}

Sanna Salo (i) http://orcid.org/0000-0003-0826-5700

\section{References}

Andersen, J. G., \& Björklund, T. (1990). Structural changes and new cleavages: The Progress parties in Denmark and Norway. Acta Sociologica, 33(3), 195-217.

Armingeon, K. (2012). The politics of austerity: What political parties can do and what markets want. Paper prepared for presentation at the 2012 Meeting of the American Political Science Association.

Arzheimer, K. (2018). Explaining electoral support for the radical right. In J. Rydgren (Ed.), The Oxford handbook of the radical right (pp. 143-165). Oxford: Oxford University Press.

Bechtel, M., Hainmueller, J., \& Margalit, Y. (2014). Preferences for international redistribution: The divide over the Eurozone bailouts. American Journal of Political Science, 58(4), 835-856.

Beramendi, P., Häusermann, S., Kitschelt, H., \& Kriesi, H. (2015). Introduction: The politics of advanced capitalism. In P. Beramendi, S. Häusermann, H. Kitschelt, \& H. Kriesi (Eds.), The politics of advanced capitalism (pp. 1-64). Cambridge: Cambridge University Press.

Borg, S. (2011). Valitsijoiden liikkuvuus eduskuntavaaleissa 2011. In S. Borg (Ed.), Muutosvaalit 2011 (pp. 126-138). Helsinki: Oikeusministeriön julkaisuja.

Bornschier, S. (2018). Globalization, cleavages, and the radical right. In J. Rydgren (Ed.), The Oxford handbook of the radical right (pp. 212-238). Oxford: Oxford University Press.

Bremer, B. (2017). The missing left? Economic crisis and the programmatic response of social democratic parties in Europe. Party Politics (in press).

Dolezal, M., Grande, E., \& Hutter, S. (2016). Exploring politicisation: Design and methods. In S. Hutter, E. Grande, \& H. Kriesi (Eds.), Politicising Europe: Integration and mass politics (pp. 32-60). Cambridge: Cambridge University Press. 
Dolezal, M., Hütter, S., \& Wüest, B. (2016). Exploring the new cleavage across arenas and public debate: Design and methods. In S. Hutter, E. Grande, \& H. Kriesi (Eds.), Politicising Europe: Mass politics and integration (pp. 38-62). Cambridge: Cambridge University Press.

Evans, G., \& Tilley, J. (2012). How parties shape class politics: Explaining the decline of the class basis of party support. British Journal of Political Science, 42(1), 137-161.

Grittersová, J., Indridason, I. H., Gregory, C. C., \& Crespo, R. (2016). Austerity and niche parties: The electoral consequences of fiscal reforms. Electoral Studies, 42, 276-289.

Grönlund, K., \& Westinen, J. (2011). Puoluevalinta. In S. Borg (Ed.), Muutosvaalit 2011 (pp. 156187). Helsinki: Oikeusministeriön julkaisuja.

Häusermann, S., Picot, D., \& Geering, D. (2013). Review article: Rethinking party politics and the welfare state - recent advances in the literature. British Journal of Political Science, 43, 221-240.

Helleiner, E. (2012). Multilateralism reborn? International cooperation and the global financial crisis. In N. Bermeo \& J. Pontusson (Eds.), Coping with crisis: Government reactions to the great recession (pp. 65-90). New York: Russell Sage Foundation.

Hobolt, S. B., \& Tilley, J. (2016). Fleeing the centre: The rise of challenger parties in the aftermath of the euro crisis. West European Politics, 39(5), 971-991.

Hutter, S., \& Grande, E. (2014). Politicizing Europe in the national electoral arena: A comparative analysis of five west European countries, 1970-2010. Journal of Common Market Studies, 52(5), 1002-1018.

Hutter, S., Grande, E., \& Kriesi, H. (2016). Politicising Europe: Mass politics and integration. Cambridge: Cambridge University Press.

Jokela, J. (2015). Finland and the Eurozone crisis. In P. Bäckman, J. H. Nielsen, J. Jokela, J. Lewander, \& G. von Sydow (Eds.), Same, same but different: The Nordic EU members during the crisis. Occasional Paper No. 1. Swedish Institute for European Policy Studies.

Kitschelt, H. (1995). The radical right in Western Europe: A comparative analysis. Ann Arbor: University of Michigan Press.

Kitschelt, H. (2018). Party systems and radical right-wing parties. In J. Rydgren (Ed.), The Oxford handbook of the radical right. Oxford: Oxford University Press.

Kleinnijenhuis, J., de Ridder, J. A., \& Rietberg, E. M. (1997). Reasoning in economic discourse: An application of the network approach to the Dutch press. In Text analysis for the social sciences: Methods for drawing statistical inferences from texts and transcripts (pp. 191-207). Mahwah: Erlbaum.

Kriesi, H. (1999). Movements of the left, movements of the right: Putting the mobilization of two new types of social movement into political context. In H. Kitschelt, P. Lange, G. Marks, \& J. D. Stephens (Eds.), Continuity and change in contemporary capitalism (pp. 398-423). Cambridge, UK: Cambridge Univ. Press.

Kriesi, H., Grande, E., Dolezal, M., Helbling, M., Höglinger, D., Hutter, S., \& Wüest, B. (2012). Political conflict in Western Europe. Cambridge: Cambridge University Press.

Kriesi, H., Grande, E., Lachat, R., Dolezal, M., Bornschier, S., \& Frey, T. (2008). West European politics in the age of globalization. Cambridge: Cambridge University Press.

Meguid, B. (2005). Competition between unequals: The role of mainstream party strategy in niche party success. American Political Science Review, 99(3), 347-359.

Michel, E. (2017). Welfare politics and the radical right: The relevance of welfare politics for the radical right's success in Western Europe. PHD Thesis. Florence: EUI.

Pontusson, J., \& Raess, D. (2012). How (and why) is this time different? The politics of economic crisis in Western Europe and the United States. Annual Review of Political Science, 15, 13-33.

Rennwald, L., \& Evans, G. (2014). When supply creates demand: Social democratic party strategies and the evolution of class voting. West European Politics, 37(5), 1108-1135.

Riker, W. H. (1986). The art of political manipulation. New Haven: Yale University Press.

Rydgren, J. (2005). Is extreme right-wing populism contagious? Explaining the emergence of a new party family. European Journal of Political Research, 44, 413-437.

Rydgren, J. (2007). The sociology of the radical right. Annual Review of Sociology, 33, 241-262.

Rydgren, J. (2008). Immigration sceptics, xenophobes, or racists? Radical right-wing voting in six West European countries. European Journal of Political Research, 47, 737-765. 
Rydgren, J. (2013). Class politics and the radical right. London: Routledge.

Rydgren, J. (2017). Radical right-wing parties in Europe: What's populism got to do with it? Journal of Language and Politics: Forthcoming.

Rydgren, J. (2018). The radical right: An introduction. In J. Rydgren (Ed.), The Oxford handbook of the radical right (pp. 1-16). New York: Oxford University Press.

Salo, S. (2017). The curious prevalence of austerity: Economic ideas in public debates on the Eurozone crisis in Ireland and Finland, 2008-2012. PhD thesis. EUI.

Schattschneider, E. E. (1975 [1960]). The semisovereign people: A realist's view of democracy in America. London: Wadsworth.

Spies, D. (2013). Explaining working-class support for extreme right parties: A party competition approach. Acta Politica, 48, 296-325.

Spies, D., \& Franzmann, S. T. (2011). A two-dimensional approach to the political opportunity structure of extreme right parties in Western Europe. West European Politics, 34, 1044-1069.

Statham, P., \& Trenz, H.-J. (2013). How European union politicization can emerge through contestation: The constitution case. Journal of Common Market Studies, 51(5), 965-980.

Streeck, W. (2014). Buying time: The delayed crisis of democratic capitalism. London: Verso.

Ward, H., Ezrow, L., \& Dorussen, H. (2011). Globalization, party positions, and the median voter. World Politics, 63(3), 509-547.

Ylä-Anttila, T. (2017). The populist toolkit. Finnish populism in Action 2007-2016. PhD Thesis. Publications of the Faculty of Social Sciences (59), University of Helsinki.

Ylä-Anttila, T., \& Ylä-Anttila, T. (2015). Exploiting the discursive opportunity of the Euro crisis the rise of the Finns Party. In H. Kriesi \& T. S. Pappas (Eds.), European populism in the shadow of the great recession (pp. 57-72). Colchester, UK: ECPR Press. 